Keywords:

Parque do Espinilho

Natural regeneration

Livestock farming

Histórico:

Recebido 31/08/2016

Aceito 04/05/2017

Palavras chave:

Parque do Espinilho

Regeneração natural

Pecuária

+Correspondência: cristina_redin@yahoo.com.br

DOI:
Cristina Gouvêa Redin ${ }^{+}$, Solon Jonas Longhi', José Miguel Reichert', Kelen Pureza Soares', Miriam Fernanda Rodrigues', Luciano Farinha Watzlawick ${ }^{2}$

\section{GRAZING CHANGES THE SOIL-PLANT RELATIONSHIP IN THE TREE- REGENERATION STRATUM IN THE PAMPA OF SOUHTERN BRAZIL}

ABSTRACT: Despite being prominent in flora, the region of the Parque Estadual do Espinilho located in the Pampas of southern Brazil, where dense herbaceous stratum and isolated trees make this region suitable for livestock farming, has received little attention. The objective of the study was to analyze floristic and edaphic changes imposed by livestock farming in two areas of the park, the first under livestock grazing and the second protected from grazing (livestock-excluded) for five years. We evaluated soil physical properties of and the herbaceous aboveground biomass in order to investigate relationships with key regenerating tree species. A sampling unit of 2 ha was installed in both areas, each composed of 200 subunits. Inventory of regenerating trees and herbaceous aboveground biomass, soil sampling, and soil penetration resistance tests were done in 50 subunits. The results, which were evaluated by Student's t-test, exhibited variations between the two areas in regards to floristic and environmental factors. The abundance of the $P$. affinis and $V$. caven species and the variables of soil penetration resistance, soil bulk density, gravimetric moisture and herbaceous aboveground biomass differ significantly between the two areas. Principal coordinates analysis (PCOA) allows to infer that variables such as soil bulk density, penetration resistance and the abundance of $V$. caven species exhibit higher values in the area under gazing, while gravimetric moisture, aboveground biomass and abundance of $P$. affinis are higher in the area under livestock-excluded, showing that significant changes occur over just five years of livestock-excluded from the area.

\section{- PASTEjo ALTERA A RELAÇÃo SOlO-PLANTA NO ESTRATO REGENERANTE ARBÓREO NO PAMPA GAÚCHO}

RESUMO: A região do Parque Estadual do Espinilho, inserida nos domínios fitogeográficos da Savana Estépica Parque, ainda é pouco estudada, apesar de ser destaque na flora sulina. Características como denso estrato herbáceo e árvores isoladas configuram-na como propícia à pecuária. Objetivou-se analisar alterações florísticas e edáficas impostas pelo pastejo em duas áreas do Parque, a primeira sob pastejo e a segunda protegida por cinco anos. Foram avaliadas propriedades físicas do solo e biomassa aérea do estrato herbáceo, visando investigar relações com as principais espécies arbóreas regenerantes. Foi instalada uma unidade amostral de $2 \mathrm{ha}$ em ambas as áreas, compostas por 200 subunidades cada. O inventário do estrato regenerante, as coletas para análises de solo, biomassa aérea do estrato herbáceo e testes de resistência do solo à penetração foram realizados em 50 subunidades. Os resultados avaliados pelo teste t de Student demonstram que há variações entre florística e fatores ambientais aferidos entre as duas áreas. A abundância das espécies P. affinis e V. caven e as variáveis resistência do solo à penetração, densidade do solo, umidade gravimétrica e biomassa aérea do estrato herbáceo diferem significativamente. A análise exploratória de ordenação (PCOA) permite inferir que variáveis densidade do solo, resistência à penetração e abundância de espécies de $V$. caven apresentam maiores valores em área com pastejo, e umidade gravimétrica, biomassa aérea e abundância de $P$. affinis são maiores em área protegida, configurando significativas mudanças ao longo de apenas cinco anos de exclusão.

' Federal University of Santa Maria - Santa Maria, Rio Grande do Sul, Brazil

2 State University of Central-West - Guarapuava, Paraná, Brazil 


\section{INTRODUCTION}

Flora composition of a region with habitats delimited by environmental factors (morphoclimatic, geomorphological and edaphic) may be indicative of the ecology and species distribution (SCHORN, 1992). The combined effect of these factors is responsible for the occurrence of endemic taxa, such as those occurring in the Savana Estépica Parque (IBGE, 1992). This plant formation is maintained in a continuous preservation area in the Parque Estadual do Espinilho conservation unit, which is located in the city of Barra do Quaraí, state of Rio Grande do Sul (RS). In RS, the Savana Estépica Parque is typically associated with sedimentary plains (ALVES; MARCHIORI, 20I I).

Morphoclimatic and geomorphological factors influence the patterns of structure and distribution of plant species in the Parque do Espinilho (FERNANDES, 1998). However, flora composition and dominant species has been influenced by grazing and fire regimes, which change the nature of the soil (PILLAR; QUADROS, 1997). Thus, understanding the association between soil and vegetation is essential to the management of preservation areas, but research on the subject is still incipient, especially in the Brazilian Savana Estépica Parque.

Changes in soil properties result in the reduction of the herbaceous stratum and modification in the composition of native species when the areas are subjected to extensive livestock farming, since grazing is an agent of biological disturbance. Most studies that assess the effect of livestock management on the floristic population structure were designed to compare populations in fragments subjected to different grazing intensities (VARGAS et al., 2002). Grazing and changes in the floristic composition of the pasture significantly affect the soil physical condition (CAPURRO et al., 2002, 2004a,b, 2014).

Understanding the relationship between the vegetation patterns and the ecosystem can be obtained using a statistical sorting procedure by means of multivariate analysis, in addition to tests of significance between means (FELFILI, 2007).

The objective of the study was to investigate the associations between soil physical properties, herbaceous aboveground biomass and the occurrence of regenerating species in two areas of the Savana Estépica Parque, one under livestock grazing and another livestock-excluded for five years.

\section{MATERIAL AND METHODS}

\section{Study area}

The study was conducted in an area of the Parque Estadual do Espinilho in the city of Barra do
Quaraí. The park is located in the extreme southwest region of the state of Rio Grande do Sul, between the geographical coordinates of 30'12'26 "S and 57'33' I7" $\mathrm{W}$, with an average altitude of $96 \mathrm{~m}$ (Figure I). The climate is humid subtropical (Cfa) according to Köppen climate classification (MORENO, 196I). Rainfall is well distributed throughout the year, with annual average between 1300 and $1500 \mathrm{~mm}$, but with water deficits in warmer months (ALMEIDA, 1996).

The area is situated on quaternary lands of the morphostructural domain of the Bacia Sedimentar do Paraná (ALVES, 20I2), in the geomorphological province of Cuesta del Haedo, where volcanic spills of the Serra Geral formation are associated to sandstones of the Botucatu formation, and the sedimentary deposits are represented by the Guterres alloformation and the Touro Passo formation (EVALDT et al., 2014). Chernossolos Ebânicos Carbonáticos vertissólicos are found in the western part of the state (STRECK et al., 2008).

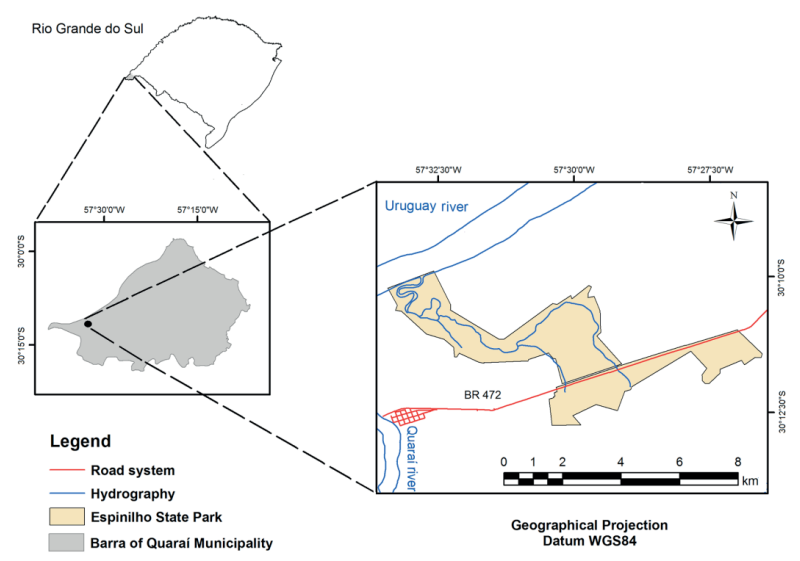

FIGURE I Location of the two sampling units installed in the Parque Estadual do Espinilho.

The natural vegetation belongs to the floristic domains of the Savana Estépica. Parque, which is characterized by a dense herbaceous stratum and a tree stratum composed of isolated and heliophilous individuals. Tree genera such as Prosopis, Aspidosperma and Vachellia are found in this physiognomy (IBGE, 20I2).

\section{Sampling Units}

Two areas were selected for analysis: one used for extensive farming (grazing) with cattle and horse, and another kept under livestock-excluded for five years. In each area, a sampling unit of 2 ha $(100 \times 200 \mathrm{~m})$ was delimited, and each unit was divided into 200 subunits of $100 \mathrm{~m}^{2}(10 \times 10 \mathrm{~m})$. 
The floristic inventory, soil sampling and aboveground biomass collection were done in 50 subunits of each area. A sampling area $0.25 \mathrm{~m}^{2}$ was defined for aboveground biomass collection, and a single collection was made for soil, vegetation and aboveground biomass data.

\section{Soil physical properties}

To determine soil bulk density (Bd), preservedstructure samples were collected in metallic rings (5.7 $\mathrm{cm}$ in diameter and $3.0 \mathrm{~cm}$ in height) in $0.00-0.10 \mathrm{~m}$ and 0.10-0.20 m soil depths. The samples were taken to the laboratory, where they were kept in an oven at $105^{\circ} \mathrm{C}$ until constant weight (EMBRAPA, 1997). Two collections were carried out for each profile layer.

Soil samples with disturbed structure were collected from the same layer for the determination of gravimetric moisture and particle size distribution of the soil. Soil gravimetric moisture $(\theta g)$ was obtained by the difference between the wet and dry weight, divided by the dry weight. Soil particle size distribution was determined by the Pipette method (EMBRAPA, 1997) after dispersion following Suzuki et al. (2015). Soil penetration resistance (PR) was determined with an impact penetrometer (Stolf model), where the depth of penetration in each of five impacts was measured with a tape measure, and RP calculated using the equation developed by Stolf (199I).

\section{Vegetation}

Data regarding the total height and diameter at ground height (DGH) of all the individuals of each subunit with minimum total height of $15 \mathrm{~cm}$ and $\mathrm{DGH}<8 \mathrm{~cm}$ were collected to assess natural tree regeneration. The botanical classification was done according to the APG III system (2009).

To determine the herbaceous aboveground biomass per hectare, all herbaceous plant material above ground level was collected by scraping. After the collection, the plant material was dried in an oven at 70 ${ }^{\circ} \mathrm{C}$ until constant weight.

\section{Statistical analysis}

The significance edaphic and floristic factors variations between the two study areas was tested using Student's t-test at $5 \%$ significance level. Subsequently, the data that varied significantly were submitted to exploratory analysis of principal coordinate analysis (PCoA), by using the MULTIV software (PILLAR, 1997), to synthetically represent the dataset for better visualization. The analysis was based on Euclidean distances between pairs of sampling units, and the significance of ordination axes was assessed by selfresampling (PILLAR, 1999).

\section{RESULTS AND DISCUSSION}

\section{Soil physical properties}

Soil bulk density, gravimetric moisture and soil penetration resistance differed significantly between the studied areas, whereas particle size distribution did not (Table I). Soil bulk density in the area under livestock grazing was higher in the subsurface layer (0.10-0.20 m) than in the surface layer $(0.00-0.10 \mathrm{~m})$, while the behavior was contrary for the area under livestock-excluded.

TABLE I Soil physical properties in two soil layers, number of individuals of the key species undergoing natural regeneration and herbaceous aboveground biomass of the Savana Estépica Parque area with and without (exclusion) grazing for five years.

\begin{tabular}{|c|c|c|c|c|c|c|c|}
\hline \multirow[t]{2}{*}{ Variables } & \multicolumn{2}{|c|}{ Grazing } & \multicolumn{2}{|c|}{ Exclusion } & \multirow[t]{2}{*}{$\mathrm{t}$} & \multirow{2}{*}{\multicolumn{2}{|c|}{$\mathrm{p}$}} \\
\hline & Mean & SD & Mean & SD & & & \\
\hline \multicolumn{8}{|c|}{ Soil physical properties } \\
\hline \multicolumn{8}{|c|}{$0.00-0.10 \mathrm{~m}$} \\
\hline $\begin{array}{l}\text { Bulk density } \\
\left(\mathrm{g} \cdot \mathrm{cm}^{-3}\right)\end{array}$ & 1.30 & 0.08 & I.II & 0.08 & 11.10 & $<0.001$ & s \\
\hline $\begin{array}{l}\text { Gravimetric moisture } \\
\left(g \cdot g^{-1}\right)\end{array}$ & 40.92 & 6.68 & 46.39 & 7.44 & -3.87 & $<0.001$ & $s$ \\
\hline Total sand (\%) & 46.06 & 4.61 & 46.06 & 4.61 & 0.00 & 0.500 & ns \\
\hline Fine sand (\%) & 25.81 & 3.23 & 25.81 & 3.23 & 0.00 & 0.500 & ns \\
\hline Coarse sand (\%) & 20.25 & 3.52 & 20.25 & 3.52 & 0.00 & 0.320 & ns \\
\hline Silt (\%) & 40.99 & 5.07 & 40.99 & 5.07 & 0.00 & 0.500 & ns \\
\hline Clay (\%) & 12.95 & 1.74 & 12.95 & 1.74 & 0.00 & 0.500 & ns \\
\hline \multicolumn{8}{|c|}{$0.10-0.20 \mathrm{~m}$} \\
\hline Bulk density $\left(\mathrm{g} \cdot \mathrm{cm}^{-3}\right)$ & 1.34 & 0.10 & 1.10 & 0.08 & 13.55 & $<0.001$ & $s$ \\
\hline $\begin{array}{l}\text { Gravimetric moisture } \\
\left(\mathrm{g} \cdot \mathrm{g}^{-1}\right)\end{array}$ & 37.79 & 5.12 & 43.60 & 9.21 & -3.90 & $<0.001$ & $s$ \\
\hline Total sand (\%) & 46.04 & 3.71 & 45.69 & 3.86 & 0.00 & 0.320 & ns \\
\hline Fine sand (\%) & 25.12 & 4.63 & 25.15 & 4.00 & 0.00 & 0.500 & ns \\
\hline Coarse sand (\%) & 20.93 & 4.63 & 20.54 & 4.04 & 0.00 & 0.320 & ns \\
\hline Silt (\%) & 40.85 & 4.08 & 40.89 & 4.15 & 0.00 & 0.500 & ns \\
\hline Clay $(\%)$ & 13.11 & 1.77 & 13.42 & 1.77 & 0.00 & 0.500 & ns \\
\hline $\begin{array}{ll}\begin{array}{l}\text { Penetration resistance } \\
(\mathrm{MPa})\end{array} \\
\end{array}$ & 4.71 & 0.43 & 2.07 & 0.01 & 43.86 & $<0.001$ & $s$ \\
\hline \multicolumn{8}{|c|}{ Vegetation (number of individuals or biomass) } \\
\hline Prosopis affinis & 0.23 & 0.48 & 2.27 & 1.51 & -4.02 & $<0.001$ & s \\
\hline Vachellia caven & 2.40 & 1.88 & 0.06 & 0.24 & 6.87 & $<0.001$ & s \\
\hline Schinus polygamous & 0.04 & 0.14 & 0.06 & 0.20 & -0.58 & 0.281 & ns \\
\hline Celtis ehrenbergiana & 0.52 & 1.20 & 0.10 & 0.42 & 2.33 & 0.011 & ns \\
\hline Biomass $(\mathrm{g})$ & 67.48 & 20.57 & 170.83 & 66.27 & 13.55 & $<0.001$ & $s$ \\
\hline
\end{tabular}


A lower soil bulk density in the surface layer of the area under livestock grazing is possibly due to a higher concentration of roots and the accumulation of organic matter (CAPURRO et al., 2002), as well as to the effect of the wetting and drying cycles in a more intense evaporation process (REINERT et al., 2008). However, soil bulk density was higher in both layers of the area under livestock grazing in comparison to the livestockexcluded area (Table I). The greatest difference in bulk density between the two areas was in the subsurface layer, where higher values were found in the area under livestock grazing.

The difference in properties influenced by soil structure, such as higher bulk density, demonstrates the effect of grazing for long periods. Magalhães et al. (200I) also observed an increase in bulk density at 0.00 $0.10 \mathrm{~m}$ in an area of native vegetation that was replaced by livestock farming and kept under grazing for 6 years. The effect of animal trampling during grazing is normally restricted to the surface layer of the soil (REICHERT et al., 2007; COLLARES et al., 201 I; KUNZ et al., 2013; CECAGNO et al., 2016), unlike the subsurface compaction observed in agricultural and forest soils (REICHERT et al., 2007, 2009, 20 I6b; MENTGES et al., 2016). However, as the effect of trampling is cumulative, applied tension can propagate to somewhat deeper soil layers (COLLARES et al., 20l I). Since the effect of the wetting and drying cycles, root growth and accumulation of organic matter is lower in the subsurface layer, the soil resilience capacity is lower than in areas kept under livestock-excluded, where there is no grazing.

Soil penetration resistance was approximately $56.13 \%$ higher and the gravimetric moisture was $12.55 \%$ lower in the area under livestock grazing compared to the livestock-excluded area (Table I). Penetration resistance was high (4.7I $\mathrm{MPa})$ in the area under livestock grazing and greater than $2.5 \mathrm{MPa}$, which is considered restrictive to the proper growth of the root system of grasses (IMHOFF et al., 2000). Resistance was $2.06 \mathrm{MPa}$ in the fallow area (Table I).

A greater resistance to root penetration in the area under livestock grazing occurs mainly due to trampling and grazing, since grazing reduces the amount of biomass and provides greater amplitude in moisture and less protection to the soil surface (FIDALSKI; ALVES, 2015; CECAGNO et al., 2016). As the trampling of sheep and cattle exerts pressures reaching 350 to $400 \mathrm{kPa}$, grazing provides direct interference in compression and penetration resistance (PROFFITT et al., 1993; NEIVA JUNIOR et al., 20I5). Maintaining surface residue is important strategy to partially reducing the propagation of surface-applied stress deeper into the soil profile (REICHERT et al., 20l6a).

\section{Natural tree regeneration and biomass of the herbaceous stratum}

Seven tree species were identified in natural regeneration of the Savana Estépica Parque. A total of 129 regenerating individuals were found in the area under livestock grazing, and 66 in the livestockexcluded area. Of these individuals, $P$. affinis (6), V. caven (95), Chrysophyllum marginatum (Hook. \& Arn.) Radlk. (I), Schinus polygamus (Cav.) Cabrera. (I) and Celtis ehrenbergiana (Klotzsch) Liebm. (26) were found in the area under livestock grazing, while $P$. affinis (5I), $V$. caven (3), S. polygamus (2), Solanum sp. L. (2), C. ehrenbergiana (5) and Sapium haematospermum Müll.Arg. (3) were found in the livestock-excluded area.

The species most frequently found in both areas were $V$. caven, $P$. affinis, $C$. ehrenbergiana and S. polygamus, totaling $98,57,31$ and 3 individuals, respectively. The other three species (Solanum sp, S. haematospermum and C. marginatum) were found in only one of the areas.

Under livestock grazing, V. caven was the dominant species with 95 individuals, equivalent to $97 \%$ of the specimens and represents $73.64 \%$ of the total individuals, whereas $P$. affinis, which is a taxon characteristic of this vegetation type (MARCHIORI; LONGHI, 1985), represents only $5 \%$. Other species such as $\mathrm{S}$. polygamus and $C$. ehrenbergiana also had a low number of specimens in the area under livestock grazing.

The livestock-excluded area had more individuals of $P$. affinis (5I) and rare individuals of $V$. caven, represented by $77.3 \%$ and $6 \%$ of the total number of specimens of each species, respectively. The higher percentage of $V$. caven specimens in comparison to $P$. affinis in the area under livestock grazing is probably related to the preference of grazing animals for this species. However, V. caven is a rare species even without the disturbing effect.

Grazing animals prefer the species of $P$. affinis (MARCHIORI; LONGHI, 1985). Naturally predominant species such as $P$. affinis and Prosopis nigra Griseb. are perhaps not significantly dominant due to anthropic actions (REDIN et al., 20I I). Therefore, it is necessary to protect $P$. affinis undergoing natural regeneration in the area under livestock grazing (MARCHIORI; ALVES, 20I I).

The herbaceous aboveground biomass was $60.5 \%$ higher in the fallow area $\left(6833.26 \mathrm{~kg} \cdot \mathrm{ha}^{-1}\right)$ compared to the area under livestock grazing $\left(2699.15 \mathrm{~kg} \cdot \mathrm{ha} \mathrm{H}^{-1}\right)$. According to Sundriyal (1992), grasses increase in biomass under 
low grazing intensity or without grazing, and decrease under high-intensity grazing, as evidenced in this study. The results show that the increase in aboveground biomass in the livestock-excluded area is mutually a cause and consequence of soil structure improvement due to the presence of effective root systems contributing to the process of aggregate formation and stabilization (CAPURRO et al., 2002; WOHLENBERG et al., 2004).

\section{Soil-plant relationship}

$V$. caven was the most frequent species undergoing natural regeneration in the area under livestock grazing, while there were a low number of specimens found undergoing natural regeneration in the livestock-excluded area. The heliophilic character of $V$. caven probably explains this behavior, since the increase in herbaceous aboveground biomass causes a lower incidence of light on the soil surface.

With increased soil cover, the difficulties for germination and establishment of tree species are higher, especially when dealing with heliophilous species such as V. caven (CHEUNG et al., 2009). In areas of natural distribution of the Prosopis genus, Giménez et al. (2003) observed that the environmental impact of livestock farming and the use of fire on grasslands cause significant damage to vegetation, with invasion of these areas by species of the Celtis, Mimosa and Acacia. It is interesting to consider V. caven previously belonged to the Acacia genera.

Higher values of soil bulk density and penetration resistance in the area under livestock grazing were associated with the higher abundance of $V$. caven and lower values of aboveground biomass of herbaceous stratum and soil moisture. The study Kotchetkoff-Henriques et al. (2005) in Africa and Central America indicates that soil physical and chemical properties influenced tree species distribution in physiognomies similar to those evaluated in our study.

The existing variations between sampling units and variables are explained in $47.69 \%$ in the first two axes of the graph generated by the PCoA (Figure 2). The first axis comprised $41.32 \%$ of the variation with significant correlation associated to positive scores with resistance to soil penetration (0.952), soil bulk density in the subsurface layer (0.89) and superfacemost layer (0.86I), and abundance of $V$. caven (0.6527). Significant correlations associated to negative scores were a result of the aboveground biomass $(-0.729)$ and the abundance of $P$. affinis (-0.408). The second axis captured $6.37 \%$ of the existing variation. The sampling units of grazing and livestock-excluded areas were separated based on floristic and edaphic properties, which show the dissimilarity between the two study sites (Figure 2).

With the exclusion of grazing, the vegetation loses the agent responsible for maintaining its initial condition and tends to change (BOLDRINI et al., 1996), which is in accordance to the variations evidenced in our study.

The fact that there are differences in the number of $V$. caven and $P$. affinis individuals between the areas is possibly due to the effect of grazing and the influence of the herbaceous stratum on the incidence of light on the soil. As for soil physical properties, there is a reduction in bulk density and penetration resistance and an increase in gravimetric moisture.

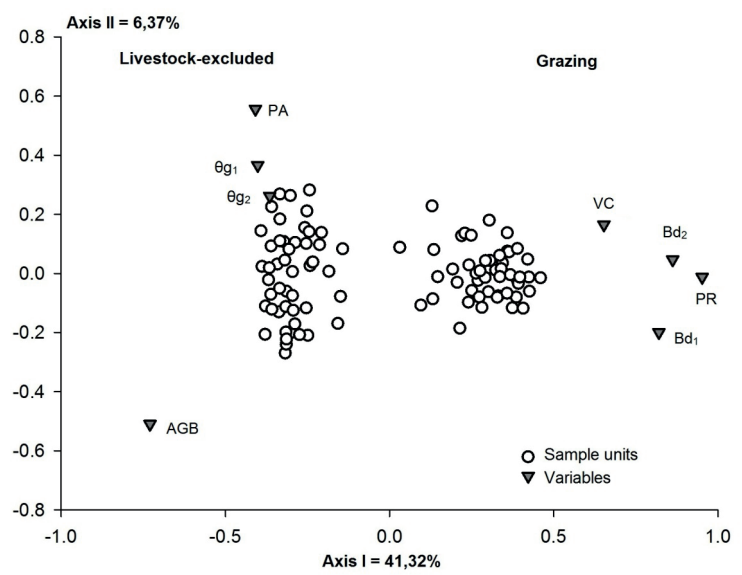

FIGURE 2 Ordination of the first two axes of the PCoA of the sampling subunits installed in the Savana Estépica Parque (grazing and livestock-excluded area) for soil bulk density $(\mathrm{BdI}=$ soil density $(0.00$ to $0.10 \mathrm{~m}) ; \mathrm{Bd} 2=$ soil density $(0.10-0.20 \mathrm{~m})$, soil penetration resistance $(P R)$, gravimetric moisture $(\theta \mathrm{gl}=$ gravimetric moisture $(0.00-0.10 \mathrm{~m}), \theta \mathrm{g} 2$ $=$ gravimetric moisture $(0.10-0.20 \mathrm{~m})$, herbaceous aboveground biomass (AGB) and abundance of Prosopis affinis (PA) and Vachellia caven (VC).

\section{CONCLUSIONS}

Soil penetration resistance, soil bulk density, gravimetric moisture and herbaceous aboveground biomass differed significantly between the livestock grazing and livestock-excluded areas. The evaluated environmental factors explain the variation in the abundance of $V$. caven in natural regeneration. The species is inhibited by shading on the soil and favored by grazing. In the absence of grazing, $P$. affinis exhibited a larger number of individuals. The sampling subunits installed in the grazing and livestock-excluded areas were dissimilar, which is characterized mainly by changes in soil physical properties and natural vegetation, due to the trampling and grazing of the animals, respectively. The notable changes found in this study occurred in just five years of livestock exclusion from the area. 


\section{REFERENCES}

ALMEIDA, J. O solo nos grandes domínios morfológicos do Brasil e desenvolvimento sustentado - Solo dos Pampas. Viçosa, Sociedade Brasileira de Ciência do Solo, p. 2088-306, 1996.

ALVES, F. da S. Fitogeografia da região do Jarau - Quaraí/RS. 20I2. IOI p. Tese (Doutorado em Engenharia Florestal) Universidade Federal em Santa Maria, Santa Maria.

ALVES, F. da S.; MARCHIORI, J.N.C. O inhanduvá (Prosopis affinis Spreng.) no Rio Grande do Sul. 5 - Ocorrência natural na várzea do rio Santa Maria, Rosário do Sul. Balduinia, Santa Maria, n. 27, p. I-7, abr. 201 I.

APG III. The angiosperm phylogeny group III. An update of the angiosperm phylogeny group classification for the orders and families of higher plants: APG III. Botanical Journal of the Linnean Society, London, v. 161, n.2, p. 105-121, oct. 2009.

BOLDRINI, I.I.; EGGERS, L. Vegetação campestre do sul do Brasil: Dinâmica de espécies à exclusão do gado. Acta Botanica Brasilica, São Paulo, v. I0, n. I, p.37-50, jan. 1996.

CAPURRO, E.P.G.; REICHERT, J.M.; REINERT, D.J.; PRECHAC, F.G. Atributos do solo e biomassa radicular após quatro anos de semeadura direta de forrageiras de estação fria em campo natural dessecado com herbicidas. Revista Brasileira de Ciência do Solo, Viçosa, v.26, n. I, p.2I I223, jan/mar. 2002.

CAPURRO, E.P.G.; REICHERT, J.M.; REINERT, D.J.; PRECHAC, F.G.; BERRETTA, E.; MARCHESI, C. Semeadura direta de forrageiras de estação fria em campo natural com aplicação de herbicidas: I. Produção de forragem e contribuição relativa das espécies. Ciência Rural, Santa Maria, v.34, n.3, p.76I-767, mai/jun. 2004a.

CAPURRO, E.P.G.; REICHERT, J.M.; REINERT, D.J.; PRECHAC, F.G.; BERRETTA, E.; MARCHESI, C. Semeadura direta de forrageiras de estação fria em campo natural submetido à aplicação de herbicidas: II. Composição botânica. Ciência Rural, Santa Maria, v.34, n.3, p.769-777, mai/jun. 2004b.

CAPURRO, E.P.G.; SECCO, D.; REICHERT, J.M.; REINERT, D.J. Compressibilidade e elasticidade de um Vertissolo afetado pela intensidade de pastejo bovino. Ciência Rural, Santa Maria, v.44, p.283-288, fev. 2014.

CECAGNO, D.; COSTA, S.E.V.G.A.; ANGHINONI, I.; KUNRATH, T.R.; MARTINS, A.P.; REICHERT, J.M.; GUBIANI, P.I.; BALERINI, F.; FINK, J.R.; CARVALHO, P.C.F. Least limiting water range and soybean yield in a long-term, no-till, integrated crop-livestock system under different grazing intensities. Soil \& Tillage Research, Amsterdam, v. 156, p. 54-62, mar. 2016.

CHEUNG, K.C.; MARQUES, M.C.M.; LIEBSCH, D. Relação entre a presença de vegetação herbácea e a regeneração natural de espécies lenhosas em pastagens abandonadas na Floresta Ombrófila Densa do Sul do Brasil. Acta Botanica Brasilica, Feira de Santa, v.23, n.4, p. I048-1056, dez. 2009.
COLLARES, G.L.; REINERT, D.J.; REICHERT, J.M.; KAISER, D.R. Compactação superficial de Latossolos sob integração lavoura: pecuária de leite no noroeste do Rio Grande do Sul. Ciência Rural, Santa Maria, v.4I, n.2, p.246-250, fev. 201 I.

EMBRAPA - Empresa Brasileira de Pesquisa Agropecuária. Centro Nacional de Pesquisa de Solos (Rio de Janeiro, RJ). Manual de métodos de análise de solos. 2.ed. Rio de Janeiro, 1997. 212p.

EVALDT, A.C.P.; BAUERMANN, S.G.; DE SOUZA, P.A. Registros polínicos para o Holoceno tardio da região da Campanha (Rio Grande do Sul, Brasil) e seu significado na história dos paleoambientes da Savana Estépica Parque. Revista Brasileira de Paleontologia, Porto Alegre, v. 17 , n.2, p.183-194, mai/ago. 2014.

FELFILI, J.M.; CARVALHO, F.A.; LÍBANO, A.M.; VENTUROLI, F.; PEREIRA, B.A.S. Análise multivariada em estudos de vegetação. Brasília: UFV, 2007. 60p.

FERNANDES, M.C. Geoecologia do maciço da TijucaRJ: uma abordagem Geo-Hidroecológica. 1998. I4I p. Dissertação (Mestrado em Geografia) - Universidade Federal do Rio de Janeiro, Rio de Janeiro.

FIDALSKI, J.; ALVES, S.J. Altura de pastejo de braquiária e carga animal limitada pelos atributos físicos do solo em sistema integração lavoura-pecuária com soja. Revista Brasileira de Ciência do Solo, Viçosa, v.39, n.3, p.864-870, mai/jun. 2015.

GIMÉNEZ, A.M.; RÍOS, N.A.; MOGLIA, J.G. Crecimiento de Prosopis nigra (Griseb.) Hieron (Algarrobo negro) em Santiago del Estero, Argentina. Foresta Veracruzana, Xapala - México, v.5, n. 2, p. 17-22, abril. 2003.

IBGE. Instituto Brasileiro de Geografia e Estatística. I.ed. Manual Técnico da Vegetação Brasileira: Sistema fitogeográfico, Inventários das formações florestais e campestres, Técnicas e manejo de coleções botânicas, Procedimentos para mapeamentos. Rio de Janeiro: 1992. 92p. (Manuais Técnicos em Geociências).

IBGE. Instituto Brasileiro de Geografia e Estatística. 2.ed. Manual técnico da vegetação Brasileira: Sistema fitogeográfico, Inventários das formações florestais e campestres, Técnicas e manejo de coleções botânicas, Procedimentos para mapeamentos. Rio de Janeiro: 2012. 27 Ip. (Manuais Técnicos em Geociências).

IMHOFF, S.; SILVA, A.P.; TORMENA, C.A. Applications of the resistance curve in the control of the physical quality of soils under grass. Pesquisa Agropecuária Brasileira, Brasília, v.35, p. 1493-I500, jul. 2000.

KOTCHETKOFF-HENRIQUES, O.; JOLY, C.A.; BERNACCI, L. Relação entre o solo e a composição florística de vegetação natural no Município de Ribeirão Preto, SP. Revista Brasileira de Botânica, São Paulo, v. 28, p. 54I-562, jul/set. 2005. 
KUNZ, M.; GONCALVES, A.D.M.A.; REICHERT, J.M.; GUIMARÃES, R.M.L.; REINERT, D.J.; RODRIGUES, M.F. Compactação do solo na integração soja-pecuária de leite em Latossolo argiloso com semeadura direta e escarificação. Revista Brasileira de Ciência do Solo, Viçosa, v.37, n.6, p.1699-1708, nov/dez. 2013.

MAGALHÃES, R. T.; KLIEMANN, H. J.; OLIVEIRA, I. P. Evolução das propriedades físico-hídricas de solos submetidos ao manejo do Sistema Barreirão. Pesquisa Agropecuária Tropical, Campina Grande, v.31, n. I, p.7-13, jun. 200I.

MARCHIORI, J.N.C.; ALVES, F.S. O Inhanduvá (Prosopis affinis Sreng.) no Rio Grande do Sul - Descrição de um parque natural na várzea do Rio Ibicuí, município de Cacequi. Balduinia, Santa Maria, v. I, n.27, p 8-14, jun. 201 I.

MARCHIORI, J.N.C.; LONGHI, S.J. Estrutura fitossociológica de uma associação natural de Parque Inhanduvá com Quebracho e Cina-cina, no Rio Grande do Sul. Ciência e Natura, Santa Maria, v.7, p. 147-162, jan. 1985.

MENTGES, M.I.; REICHERT, J.M.; RODRIGUES, M.F.; AWE, G.O.; MENTGES, L.R. Capacity and intensity soil aeration properties affected by granulometry, moisture, and structure in no-tillage soils. Geoderma, Amsterdam, v.263, n. I, p.47-59, fev. 2016

MORENO, J.A. Clima do Rio Grande do Sul. Porto Alegre: Secretaria da Agricultura, 196I, 42p.

NEIVA JUNIOR, E.; ROCHA, W.W.; PIRES, B.S.; FARNEZI, M.M.M.; DIAS JUNIOR, M.S.; FREITAS, D.F.B.; SILVA, E.B.; CARVALHO, G.A.O. Compressiblity and penetrability of Latossolo Vermelho-Amarelo Distrófico (Oxisol) under varied management systems and land uses. Revista Brasileira de Ciência do Solo, Viçosa, v.39, n. I, p.86-93, jan/fev. 2015.

PILLAR, V.D. The bootstrapped ordination reexamined. Journal of Vegetation Science, Washington, v. 10, p.95902, fev. 1999.

PILLAR, V.D.; QUADROS, F.L.F. Grassland-forest boundaries in southern Brazil. Coenoses, Gorizia, v.12, p.I19-126, jan. 1997.

PROFFITT, A.; BENDOTTI, S.; HOWELL, M.; EASTHAM, J. The effect of sheep trampling and grazing on soil physical properties and pasture growth for a red-brown earth. Australian Journal of Agricultural Research, Melbourne, v.44, p.317-331, jan. 1993.

REDIN, C.G.; LONGHI, R.V.; WATZLAWICK, L.F.; LONGHI, S.J. Composição florística e estrutura da regeneração natural do Parque Estadual do Espinilho, RS. Ciência Rural, Santa Maria, v.4I, n.7, p. I I95-I20I, jul. 20 II.

REICHERT, J. M.; SUZUKI, L. E. A. S.; REINERT, D. J.; HORN, R.; HAKANSSON, I. Reference bulk density and critical degree-of-compactness for no-till crop production in subtropical highly weathered soils. Soil \& Tillage Research, Amsterdam, v. 102, n.2, p.242-254, mar. 2009.
REICHERT, J.M.; BRANDT, A.A.; RODRIGUES, M.F.; REINERT, D.J.; BRAIDA, J.A. Load dissipation by corn residue on tilled soil in laboratory and field-wheeling conditions. Journal of the Science of Food and Agriculture, v.98, n.8, p.27052714 , set. $2016 a$.

REICHERT, J.M.; DA ROSA, V.T.; VOGELMANN, E.S.; DA ROSA, D.P.; HORN, R.; REINERT, D.J.; SATTLER, A.; DENARDIN, J.E. Conceptual framework for capacity and intensity physical soil properties affected by short and long-term (I4 years) continuous no-tillage and controlled traffic. Soil \& Tillage Research, Amsterdam, v. 158, p.123-136, mai. 2016 b.

REICHERT, J.M.; SUZUKI, L.E.A.S.; REINERT, D.J. Compactação do solo em sistemas agropecuários e florestais: identificação, efeitos, limites críticos e mitigação. In: CERETTA, C.A.; SILVA, L.S.; REICHERT, J.M. (Ed.). Tópicos em Ciência do Solo. Viçosa: Sociedade Brasileira de Ciência do Solo, v.5, 2007. p.49-134.

REINERT, D.J.; ALBUQUERQUE, J.A.; REICHERT, J.M.; AITA, C.; ANDRADA, M.M.C. Limites críticos de densidade do solo para o crescimento de raízes de plantas de cobertura em Argissolo Vermelho. Revista Brasileira de Ciência do Solo, Viçosa, v.32, n. 5, p.1805-1816, set/out. 2008.

SCHORN, L.A. Levantamento florístico e análise estrutural em três unidades edáficas em uma Floresta Ombrófila Densa Montana no Estado do Paraná. 1992. I44 p. Dissertação (Mestrado em Engenharia Florestal) Universidade Federal do Paraná, Curitiba.

STOLF, R. Teoria e tese experimental de fórmulas de transformação dos dados de penetrômetro de impacto em resistência do solo. Revista Brasileira de Ciência do Solo, Campinas, v. I5, p.229-235, set/out. 199I.

STRECK, E.V.; KAMPF, N.; DALMOLIN, R.S.D.; KLAMT, E.; NASCIMENTO, P.C. DO; SCHNEIDER, P.; GIASSON, E.; PINTO, L. F. S. Solos do Rio Grande do Sul. Porto Alegre: EMATER/RS-ASCAR, 2008. 222 p.

SUNDRIYAL, R.C. Structure, productivity and energy flow in an alpine grassland in the Garhwal Himalaya. Journal of Vegetation Science, Washington, v.3, p. I5-20, fev. 1992.

SUZUKI, L.E.A.S.; REICHERT, J.M.; ALBUQUERQUE, J.A.; REINERT, D.J.; KAISER, D.R. Dispersion and flocculation of Vertisols, Alfisols and Oxisols in Southern Brazil. Geoderma Regional, Amsterdam, v.5, p.64-70, ago. 2015.

VARGAS, O.; PREMAUER, J.; CÁRDENAS, C.A. Efecto del pastoreo sobre la estructura de la vegetación en un páramo húmedo de Colombia. Ecotrópicos, Mérida, v.I5, n.I, p.35-50, jul. 2002.

WOHLENBERG, E.V.; REICHERT, J.M.; REINERT, D.J.; BLUME, E. Dinâmica da agregação de um solo francoarenoso em cinco sistemas de culturas em rotação e em sucessão. Revista Brasileira de Ciência do Solo, Viçosa, v.28, n.5, p.89I-900, set/out. 2004. 
